\title{
Gen(d)eralized Trust
}

\section{An Experimental Approach to Interpersonal Trust and Gender Sensitivity}

\author{
Cornelius Cappelen \\ Department of Comparative Politics, University of Bergen, Bergen, Norway \\ cornelius.cappelen@uib.no \\ Jonas Linde \\ Department of Comparative Politics, University of Bergen, Bergen, Norway \\ jonas.linde@uib.no
}

\author{
Petrus Olander \\ Department of Political Science, Lund University, Lund, Sweden \\ petrus.olander@svet.lu.se
}

\begin{abstract}
In this research note, the authors examine the extent to which one gender is more trusted than the other, relying on between-subjects survey experiments fielded in Germany, Norway and the United States. The authors' findings reveal that respondents have substantially higher trust in women than in men, and that this is partly driven by gender role beliefs ascribing prosocial behavior more to women. Furthermore, across countries it is particularly trust in men that differs; trust in women is much more similar. The findings provide important insights into the sources of trust and why generalized trust differs between countries; they advance our understanding of how we relate to particular others and also groups of people with different ratios of men/women.
\end{abstract}

\section{Keywords}

interpersonal trust - social trust - gender - survey experiment - Germany - Norway USA 
Generalized, or social, trust - trust in other members of society - is one of the most studied topics in the social sciences, and an extensive empirical literature has linked it to a variety of positive outcomes, such as happiness, democracy economic development, entrepreneurship and volunteering (see Delhey et al. 2011 and Newton et al. 2018 for overviews).

In this research note, we investigate whether people differentiate their trust between women and men. While gender as a social category is omnipresent, there is little knowledge about the gender-sensitivity of trust, in particular the issue of whether one gender is more trusted than the other. To our knowledge, this is the first study to use representative population samples across countries to examine this, and we believe that our findings provide important insights into the sources of trust and why generalized trust differs between countries. Exploring which gender is the more trusted is important because people often choose whom to interact with and by implication their gender: beyond the obvious cases of face-to-face interactions people reveal, in trust situations, which gender they belong to through verbal communication in e.g. written documents (Bonein and Serra 2009).

To formulate hypotheses, we rely on studies of gender stereotyping that claim women to be more prosocial than men (Eagly 2009). From this we theorize that people trust women more and that this can partly be explained by men being seen as more selfish (less prosocial). Our findings support both hypotheses.

Employing a between-subjects design we fielded survey experiments in Norway, Germany, and the US. Representative population samples in each country were asked to answer a question about their trust in other people. Respondents in the control group were asked whether or not most people can be trusted. In two treatment groups, gender specified referents were used (can most men/women be trusted?). The countries were chosen on the account that they differ in terms of gender inequality and type of welfare system. Among the OECD countries, Norway - a social democratic welfare state - ranks high on gender equality while the US, with its liberal welfare state, ranks relatively low. Germany - classified as a conservative welfare regime - is situated in the middle (Jahan, 2016; Esping-Andersen 1990). We theorize that high gender inequality is related to a relatively high trust in women and a relatively low trust in men. This claim is supported by our findings. 
The issue of gender-sensitive trust relates to three questions (Buchan et al. 2008): a) Trust in others: is one of the genders more trusting; b) being trustworthy: does one of the genders reward trust through reciprocation more; and c) being trusted by others: is one of the genders more trusted?

Studies related to $a$ ) (using either surveys or trust games ${ }^{1}$ ) often find that women are somewhat less trusting than men (e.g. Alesina and La Ferrara 2002; Eckel and Wilson 2004; Innocenti and Pazienza 2006; Cox and Deck 2006). Studies related to $b$ ) typically employ trust games, often finding that women reciprocate more, though this result is not always significant (for a review, see Garbarino and Slonim 2009). Studies related to $c$ ) are few. Wright and Sharp (1979) used a version of Rotter's "Interpersonal Trust Scale" to specify the gender of the reference group to be trusted, finding that female psychology students were more trusted than male psychology students. ${ }^{2}$ A study of 216 female civil service employees found that the employees trusted male supervisors more than female supervisors (Jeanquart-Barone \& Sekaran 1994). Two experimental studies employing the trust (investment) game reveal mixed and weak findings (e.g. Buchan et al. 2008; Garbarino and Slonim, 2009). However, none of these previous investigations employs population representative samples, and none of them utilizes the conventional trust question in survey research: "Generally speaking, would you say that most people can be trusted or that you need to be very careful in dealing with people?"

Representative surveys increase external validity by exploring not only subgroups of the population, such as students (which is common in the experimental literature on trust), but rather samples that are representative for the full population on relevant characteristics, such as age, income, and political affiliation. It is well known that students are not necessarily representative for the full population, and that generalizing from students to the general public can be problematic when personal and attitudinal variables are used

1 In a typical trust game, subjects (first movers) in room A decide how much of a show-up fee to send an anonymous counterpart (second mover) in room B Before the game starts, all participants are informed that they money sent will be tripled by the experimenter, so that the second mover is left with three times the amount sent to her by the first mover. The second mover then decides how much money to send back of her tripled money to the first mover that she is paired with (Berg et al. 1995).

2 Rotter's ITs includes 40 items of which 25 relate to trust. Half of the trust items refer to members of specific occupational groups (e.g. politicians) and the other half to more generalized references groups (e.g. people, students). 
(e.g. Hanel and Vione 2016). Furthermore, utilizing the conventional trust question is important because our experimental results are then easily comparable to the large survey literature on trust that bases findings on this conceptualization of trust.

There are many related reasons for why one could expect people to trust women more than men; some have to do with gender role beliefs, while others relate to actual behavior of men and women in experimental settings. Regarding perceptions, evidence suggests that women are generally seen as less selfish than men. People constantly find themselves in situations where there is a conflict between some common good and the pursuit of self-interest, i.e. they face a social dilemma (Kollock 1998; Irwin et al., 2015). Some then engage in activities that are costly to themselves but that help others, e.g. sharing, comforting, and defending (Bénabou \& Tirole 2006). Others act more selfishly. Empirical findings indicate that gender role beliefs ascribe prosocial behavior more to women (Eagly, 2009; Eaton et al. 2012; Moffitt et al. 2001). Kindness and concern for others, for example, are properties more intensively ascribed to women (Diekman \& Goodfriend 2006), and women are thought to be more friendly and unselfish and other-regarding (Spence and Buckner, 2000). Moreover, women are typically thought to exhibit more empathy and compassion (Rueckert \& Naybar 2008).

Gender stereotypes, like other types of stereotyping, reflect what people observe in their daily life, e.g. when people observe women more than men to care for children, they are likely to associate women more than men with those qualities that often relate to child care, like nurturance and warmth (Eagly and Steffen, 1984: 735). Because of this stereotyping, people see women as more communal than men.

Regarding actual behavior, research in social psychology indicates that women in many non-economic situations are more socially oriented (less selfish) than men (Eagly 1987). Thus, stereotyping and actual behavior are often not far apart. In economic situations (when money is at stake), research also indicates that women are less selfish than men. In dictator games, ${ }^{3}$ some findings indicate that women donate more than their male counterparts (e.g. Eckel and Grossman 1998); and in trust games, some studies find that women return

3 In a dictator game, the dictator is given some quantity of money. He/she then decides how much of the money (say, \$10) he/she anonymously would like to give to a second participant, who initially was given nothing. Whatever amount the dictator offers to the second participant must be accepted. 
(reciprocate) more money than men, both in the United States and internationally (Croson and Buchan 1999; Garbarino and Slonim 2009).

It is also worth noticing that crime rates, especially for violent crimes, are much higher for men (Broidy \& Agnew, 1997). Evidence also suggests that women are less involved in bribery and less likely to condone bribe-taking (Swamy et al. 2001), and that higher representation of women in government correlates with lower levels of corruption (Swamy et al., 2001).

From these findings we conjecture that people will tend to trust women more than men. Ceteris paribus, it is more likely that people trust someone they believe to be e.g. friendly and unselfish (stereotyping about women), than a person they believe to be e.g. assertive, competitive, and selfish (stereotypes about men). We add to this that there often can be a match between perceptions and actual behavior, as indicated by the above cited research; and we similarly conjecture that if people in their daily lives experience women to be more pro-social (selfless) than men, they will tend to trust them more.

We thus formulate the following two hypotheses:

\section{$\mathrm{H}_{1}$ : People tend to trust women more than men.}

$\mathrm{H}_{2}$ : People trust women more than men because they believe women to be less selfish.

Furthermore, in countries where gender inequality is high, men are more likely than women to hold political offices and women are under-represented in e.g. executive positions and board seats. Consequently, men are more likely to attract media exposure. At the same time, we know that negativity in news is high (e.g. Lengauer et al., 2012), and that negative information has a much greater impact on individuals' attitudes than does positive information (e.g. Soroka, 2006). It is thus reasonable to theorize that if negative news primarily spotlights men, people will come to trust men less and women more, resulting in a gender gap in trust.

Also, we know from previous research that there is a correlation between viewing women as occupants of the domestic role - a view particularly present in countries with high levels of gender inequality - and the ascription of nice and communal attributes to women more than men (Eagly and Mladinic, 1994). All this makes us theorize that as gender inequality increases, trust in women increases and trust in men decreases. We would like to note, however, that with data from only three countries this expectation cannot be tested vigorously. 
We employed a between-subjects experimental survey design in three countries: Norway, USA, and Germany. ${ }^{4}$ In Germany and the United States, Gallup 5 surveyed 1,000 respondents in each country in December 2016. In Norway, Norstat ${ }^{6}$ administered the experiment to 1,ooo respondents in December 2017.

There is an ongoing discussion concerning how to best formulate trust questions in survey research (for a review see Lundmark et al. 2016). The most frequently used wording is: "Generally speaking, would you say that most people can be trusted or that you need to be very careful in dealing with people?"7 Following the recommendations by Lundmark et al. (2016), we have chosen a minimally balanced version of this question with an 11-point response scale, mentioning only a single viewpoint (possible to trust people) and instead balancing the question by adding "can be trusted" or "cannot be trusted" to the accompanying scale (Table 1 ).

Respondents in each country were randomly assigned to a treatment group. The first group was asked to what extent it is generally possible to trust people, the second group to what extent it is generally possible to trust men, and the third group to what extent it is generally possible to trust women.

The between-subjects design minimizes the risk of social desirability bias related to gender equality; the respondents arguably feel less of an urge to be gender neutral as they only report their trust in one category. The relatively large sub-sample size in each country $(\mathrm{N} \approx 333)$ ensures that there are no large demographical differences between groups (see appendix for descriptive statistics).

We hypothesize that people trust women more than men because they believe women are more prosocial. We therefore also asked respondents the following question: "In general, who do you think is more selfish, men or

4 These surveys were preceded by a pilot survey in Norway where we ran the same experiment but did not gather the same attitudinal covariates. The treatment effect found in that pilot study is the same as the one presented here. See the online appendix for details and tests.

5 Gallup used their Kantar-panels in both Germany and USA - branded “Lightspeed/GMI". For details, see: http://www.lightspeedresearch.com/\#home.

6 Questions on individual characteristics are standard provided by the company. See Appendix 1 for details. The data collection used sampling quotas based on known population parameters. If it becomes demographically under-represented, more respondents are added. Finally, the sample is weighted so that representativeness is accurate.

7 Some version of this trust question is used by many of the most well-known cross national surveys that explores people's values and beliefs, including the American General Social Surveys (GSs), the World/European Values Survey (wvs), and the European Social Survey (ESS) (Nannestad, 2008). 


\section{Group 1}

In your opinion, to what extent is it generally possible to trust people?

People cannot generally be trusted

People can generally be trusted

$\begin{array}{lllllllllll}\mathrm{O} & 1 & 2 & 3 & 4 & 5 & 6 & 7 & 8 & 9 & 10\end{array}$

\section{Group 2}

In your opinion, to what extent is it generally possible to trust men?

Men cannot generally be trusted

Men can generally be trusted

$\begin{array}{lllllllllll}0 & 1 & 2 & 3 & 4 & 5 & 6 & 7 & 8 & 9 & 10\end{array}$

\section{Group 3}

In your opinion, to what extent is it generally possible to trust women?

Women cannot generally be trusted

Women can generally be trusted

$\begin{array}{lllllllllll}\mathrm{O} & 1 & 2 & 3 & 4 & 5 & 6 & 7 & 8 & 9 & 10\end{array}$

women?"8 Acting unselfishly is at the heart of what it means to engage in prosocial behavior (Bénabou \& Tirole 2006). We use these responses to probe if perceptions of gender and prosocial behavior affect trust.

\section{$4 \quad$ Results}

The main result of the experiment is consistent across the countries. On average, people report more trust in women than in men and (the control group) 'people' (Figure 1). In Norway the difference is moderate: In the control group trust in people $\left(\mathrm{M}_{\mathrm{p}}\right)$ - the average trust level is 6.89. The average for those asked about trust in men $\left(\mathrm{M}_{\mathrm{m}}\right)$ is 7.66 , while the group asked about women $\left(\mathrm{M}_{\mathrm{w}}\right)$ averages 8.23. The gender-sensitivity of trust is even stronger in Germany and the US. In Germany, the average trust levels are $\left(M_{p}\right)=4.33,\left(M_{m}\right)=5.85$, and

8 Categories: 1. Men are definitely more selfish; 2. Men are a little more selfish; 3. Men and women are equally selfish; 4 . Women are a little more selfish; 5 . Women are definitely more selfish. 


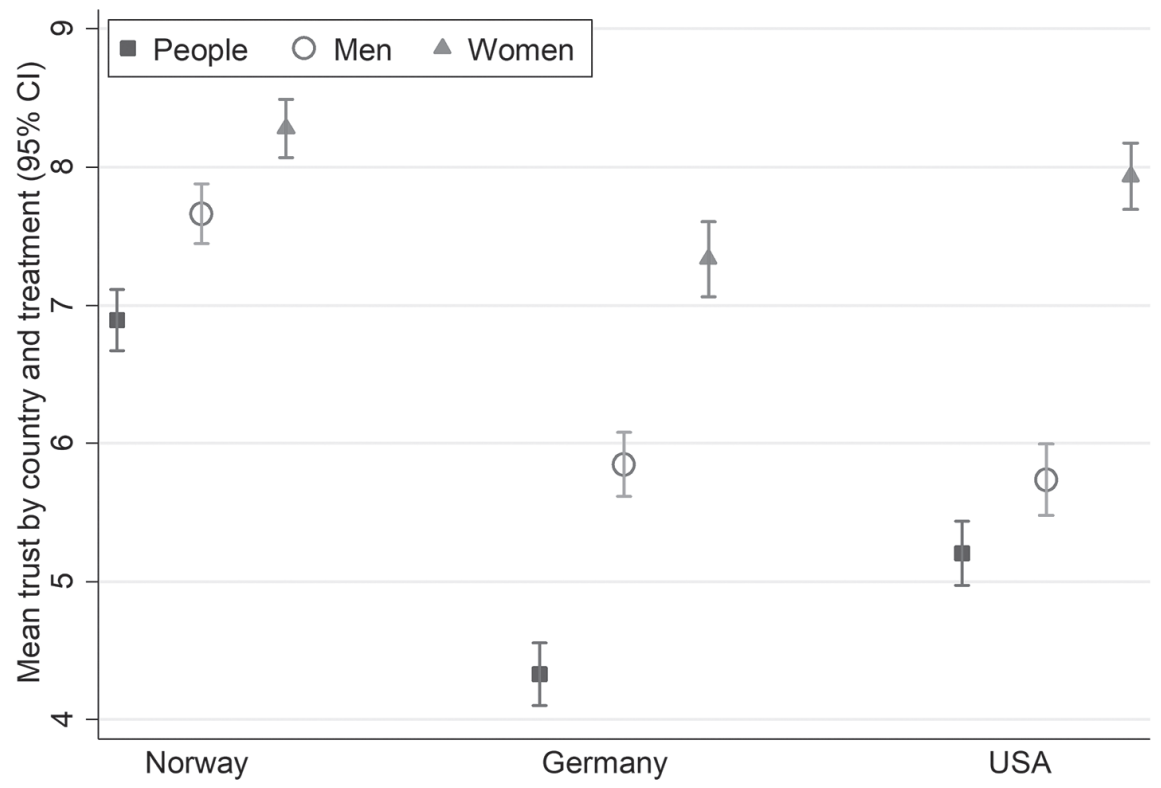

FIGURE 1 Average trust in people, men, and women

$\left(M_{w}\right)=7.33$. In the US, the corresponding levels are $\left(M_{p}\right)=5.2,\left(M_{m}\right)=5 \cdot 74$, and $\left(\mathrm{M}_{\mathrm{W}}\right)=7.93$.

All differences are substantial and statistically significant (see Table A2 for details). Thus, in line with $\mathrm{H}_{1}$, we find that people trust women more than men. It is noteworthy that trust in "people" is not an average of trust in men and women. Our data do not give a straightforward answer to this puzzle, but the following explanation strikes us as intuitively attractive. When the trust question is non-gendered, it is perceived as more general, while it is perceived as more particularized when it is gendered. Put differently, the respondents in the control group arguably have a wider circle of "others" in mind (a higher trust radius) when reporting their trust level than in the gendered groups; and we know from previous literature that trust levels are decreasing with the size of the trust radius (Delhey et al., 2011). It is not unrealistic that respondents in the control group interpret the trust question as whether they trust both men and women (a wide circle of "others"). And it is likely that they trust men and women less than they trust one particular gender. To illustrate, if 6o percent of the population trust women and 40 percent trust men, then it is impossible that more than 40 percent trust both women and men.

The gender gap in trust is particularly prominent in the US, where gender inequality is most pronounced. The gap is smallest in Norway, where gender 
inequality is low. These findings align with our theorizing that gender inequality increases the gender gap in trust. It is also noteworthy that the cross-country differences in trust in "people" and "men" are much more substantial than the corresponding difference in trust in "women". Trust in women is close to identical in Norway and the US, and not very far behind in Germany.

The respondents were also asked if they perceive men or women to be the most selfish, or equally selfish. ${ }^{9}$ We create a dummy for each treatment and use the responses to test $\mathrm{H}_{2}$. Respondents asked about trust in women are coded 1 if they perceive women to be more selfish (else o). Those asked about trust in men are coded 1 if they perceive men to be more selfish (else o). ${ }^{10}$ We run separate regressions for each treatment using those who do not think that a particular treatment is more selfish as reference category.

Figure 2 presents the correlation between trust in a particular gender and the belief that that gender is more selfish, controlling for socio-demographic factors (gender, age, education, income, having a partner, left-right position, and country dummies in the pooled sample). The results are in line with our expectations. Across samples, respondents asked about men and who think men are more selfish report substantially less trust than those asked about men and who do not consider men more selfish (reference category).

For respondents asked about women the result is somewhat different. In the US and Norway, those asked about women and who perceive women to be more selfish report lower trust in women than those who do not think women were more selfish (reference category). While the estimates are similar for Germany, the difference is not significant.

In the control group we find another interesting result. Perceiving men to be more selfish is not significantly correlated with trust in "people," indicating that people do not think of one particular gender when responding to the non-gendered trust question. If so, perceptions of selfishness should correlate with trust levels in that group. Furthermore, in line with previous research on gender stereotyping, we find that in all the countries men are more often perceived as selfish than women (Table 2).

In our pilot study in Norway, the "selfishness" question was not fielded. This is unfortunate, but helps us ensure that the selfishness question is not driving the main treatment effects, since the pilot respondents show equal patterns to those in subsequent replications (see Figure $\mathrm{A}_{1}$ and Table $\mathrm{A} 2$ in appendix).

10 For full table and alternative coding of selfishness (results are similar), see Table $\mathrm{A}_{4}$ in the appendix. 


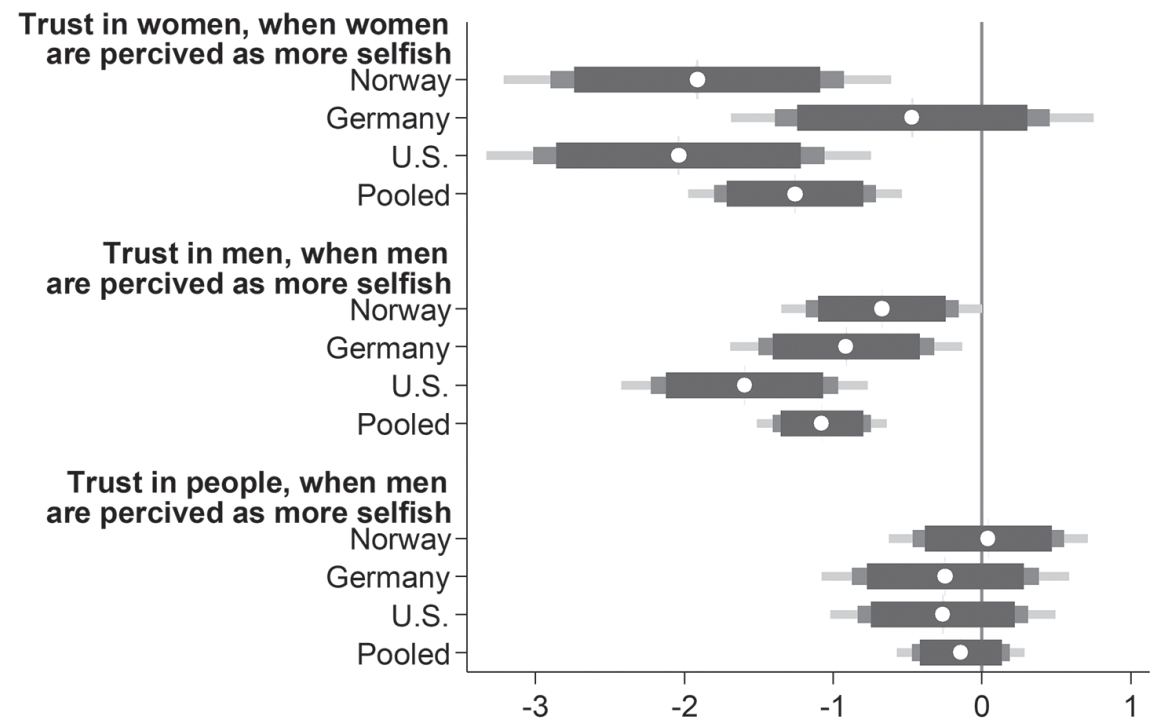

Note: Full regression models including controls are presented in Table A3.

FIGURE 2 Multivariate analysis trust, perceptions of selfishness and covariates (OLS); depicted confidence intervals: $90 \%, 95 \%, 99 \%$

TABLE 2 Views on selfishness (percent)

\begin{tabular}{lcccc}
\hline & Norway & Germany & USA & Pooled \\
\hline Men are more selfish & 31.6 & 29.6 & 24.9 & 28.7 \\
Men and women are equally selfish & 58.6 & 56.4 & 65.4 & 60.1 \\
Women are more selfish & 9.8 & 14.0 & 9.7 & 11.2 \\
Total & 100 & 100 & 100 & 100 \\
\hline
\end{tabular}

Note: The question (here in English) was "In general, who do you think is more selfish, men or women?

The overall impact that views on selfishness have on the aggregate level of the treatment effect (more trust in women than in men) is illustrated in Figure 3.

The left-hand panel is identical in terms of means to the treatment effects in Figure 1. The right-hand panel, however, excludes respondents who perceive men as more selfish. This reduces the difference between trust in men and women by 0.38 points in Germany, by 0.49 points in the US, and 0.31 points in Norway. This amounts to a 22 percent decrease of the treatment effect in the US and a 25 percent decrease in Germany. In Norway the confidence intervals 

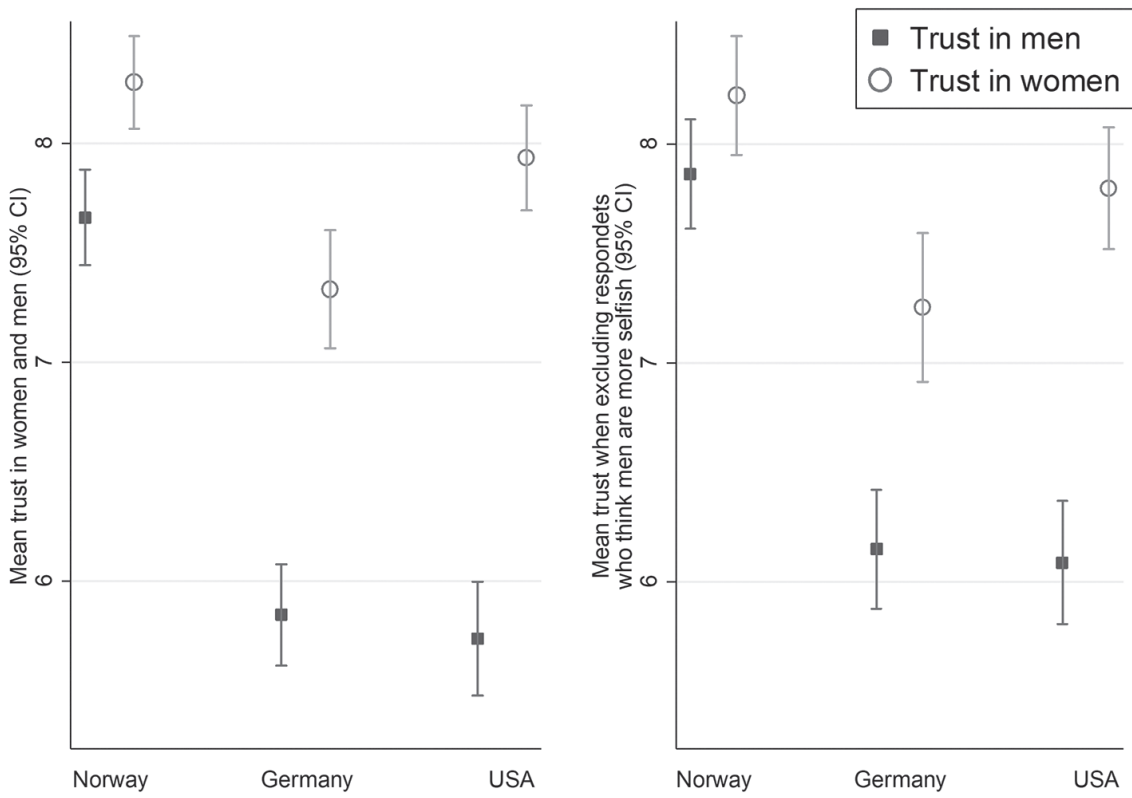

FIGURE 3 The treatment effects before/after removing respondents who perceive men as more selfish

are overlapping. Thus, while perceptions of selfishness at the individual level are linked to lower trust in both men and women, the perception that men are more selfish is much more prevalent in the population, which helps to explain why there is such a stark difference in aggregated trust in the two genders.

The study of interpersonal trust in organizations largely relies on a framework developed by Mayer et al. (1995), proposing ability, benevolence, and integrity as the bases of trustworthiness perceptions of trustors. Benevolence refers to our concern for the well-being of others, and to a large extent aligns with selfishness. Ability refers to the knowledge, skills, and aptitudes of a leader. Finally, integrity is acting according to ethical principles such as honesty. We have already presented strong indicative evidence for the argument that people trust women more than men because they believe women to be less selfish (more benevolent). We can only speculate on how women might be viewed on the other two trustworthiness dimensions. Trust based on ability is domain specific and does not necessarily translate to other trust situations. At a general level we see no reason why one gender should be considered more competent than the other. However, in specific trust situations where particular abilities are deemed important by the trustor (e.g. physical strength, mathematical skills), one gender could potentially be viewed as the more competent, 
and consequently be seen as more trustworthy. As with benevolence, integrity relates to the moral character of the trustee, e.g. the extent to which he or she is being honest, telling the truth, and admitting mistakes (following moral principles). We would argue that it is possible to have integrity without being benevolent; however, this is controversial and some think that integrity requires that the principles stood for must be those that are morally good (e.g. Graham 2001); if so, being a benevolent person (e.g. always showing concern for others) exemplifies integrity and it is possible that women are seen as having more integrity than men. To the best of our knowledge, however, this claim has never been empirically verified.

As emphasized earlier, some experimental research indicates that women are more trustworthy in their behavior than men (e.g. Croson and Buchan 1999). Our finding that people trust women more than men matches these findings. Croson and Buchan (1999) speculate that the higher level of money returned by women (in trust games) could be due to women being more altruistic than men, or that women are more likely than men to reciprocate. If these speculations hold outside the lab, they can explain the findings related to gender stereotyping that women are perceived as more selfless than men, and ultimately our finding that people trust women more.

\section{$5 \quad$ Concluding Remarks}

This note provides a steppingstone for future inquiries into an important and understudied topic; how levels of trust are affected by the gender of the object of trust. Our study shows that, in general, people trust women substantially more than men, and that this relates to people perceiving women to be more selfless than men. Moreover, when the trust question employs gender specified referents, we find that some of the cross-national variation in generalized trust cancels out, primarily due to the fact that trust levels in women are very similar across countries.

Previous research has shown that individual characteristics related to the trustor, such as age and gender, can help explain variation in trust (e.g. Nannestad, 2008). Our research highlights that also the gender of the trusted, as well as gender stereotyping, have a substantial effect on trust. According to prototype theory, developed in cognitive science by amongst other Rosch (1975), people categorize items and concepts based on a prototype or ideal representation of that category. We find it probable that people asked about trust in women are more likely to think of attributes belonging to stereotypical women, such as prosocial behavior. Those asked about trust in men are more 
likely to think about attributes belonging to stereotypical men, e.g. men being more selfish than women.

We still need to know more about what causes people to trust women more than men and how our findings manifest themselves in everyday experiences. Gendered trust levels might differ from those found in this study if they relate to people in particular roles or positions, e.g. a female politician versus a male politician or a male supervisor versus a female supervisor. Regarding cross-country comparisons and generalizability, we included only western industrialized countries; findings might be different in low-income or developing countries.

The results of our experiments give rise to an understudied question: The levels of trust in women do not differ much between the three countries. Rather, it is trust in men that varies. Furthermore, the gender gap in trust is least pronounced in Norway, a country with (relatively) low gender inequality and most pronounced in the US with (relatively) high gender inequality. Could it therefore be that at the aggregate level, gender inequality correlates negatively with trust in "people" (since it seems to reduce trust in men)? This is an interesting topic worthy of further exploration.

\section{References}

Alesina, A. and E. La Ferrara. 2002. "Who trusts others?" Journal of Public Economics 85 (2), 207-234.

Berg, J., J. Dickhaut, and K. McCabe. 1995. "Trust, reciprocity and social history." Games and Economic Behavior 10, 122-142.

Bonein, A. and D. Serra. 2009. "Gender Pairing Bias in Trustworthiness." Journal of Socio-Economics 38 (5), 779-89.

Brescoll, V. L. and T. G. Okimoto. 2010. "The Price of Power: Power Seeking and Backlash Against Female Politicians." Personality and Social Psychology Bulletin 36(7), 923-936.

Broidy, L. and R. Agnew. 1997. "Gender and Crime: A General Strain Theory Perspective." Journal of Research in Crime and Delinquency 34 (3), 275-306.

Buchan, N. R., R. T. A. Croson, and S. Solnick. 2008. "Trust and Gender: An Examination of Behavior and Beliefs in the Investment Game." Journal of Economic Behavior \& Organization 68 (3), 466-476.

Cox, J. C. and C. A. Deck. 20o6. "When are Women More Generous than Men?" Economic Inquiry 44 (4), 587-598.

Croson, R. and N. Buchan. 1999. "Gender and Culture: International Experimental Evidence from Trust Games." American Economic Review 89 (2), 386-391. 
Delhey, J. and K. Newton. 2005. “Predicting Cross-National Levels of Social Trust: Global Pattern or Nordic Exceptionalism?" European Sociological Review 21 (4), 311-327.

Delhey J., K. Newton, and C. Welzel. 2011. "How General is Trust in 'Most People'? Solving the Radius of Trust Problem." American Sociological Review 76 (5), 786-807.

Diekman, A. B. and W. Goodfriend. 20o6. "Rolling with the Changes: A Role Congruity Perspective on Gender Norms.” Psychology of Women Quarterly 30 (4), 369-383.

Eagly, A. H. 1987. Sex differences in social behavior: A social role theory interpretation. Hillsdale, NJ: Erlbaum.

Eagly, A. H. 20o9. "The His and Hers of Prosocial Behavior: An Examination of the Social Psychology of Gender." American Psychologist 64 (8), 644-658.

Eagly, A. H. and A. Mladinic. 1994. "Are People Prejudiced Against Women? Some Answers From Research on Attitudes, Gender Stereotypes, and Judgments of Competence." European Review of Social Psychology 5 (1), 1-35.

Eagly, A. H. and V. J. Steffen. 1984. "Gender stereotypes stem from the distribution of women and men into social roles." Journal of Personality and Social Psychology 46 (4), 735-754.

Eaton, N. R., K. M. Keyes, R. F. Krueger, S. Balsis, A. E. Skodol, K. E. Markon, B. F. Grant and D. S. Hasin. 2012. "An Invariant Dimensional Liability Model of Gender Differences in Mental Disorder Prevalence: Evidence from a National Sample." Journal of Abnormal Psychology 121 (1), 282-288.

Eckel, C. C. and P. J. Grossman. 1998. "Are Women Less Selfish than Men? Evidence from Dictator Experiments." The Economic Journal, 108 (448): 726-35.

Eckel, C. C. and R. K. Wilson. 2004. "Is trust a Risky Decision?" Journal of Economic Behavior \& Organization 55 (4), 447-465.

Esping-Andersen, G. 1990. The Three Worlds of Welfare Capitalism. New Jersey: Princeton University Press.

Garbarino, E. and R. Slonim. 2009. "The Robustness of Trust and Reciprocity Across a Heterogeneous US Population." Journal of Economic Behavior \& Organization 69 (3), 226-240.

Graham, J. L. 2001. “Does Integrity Require Moral Goodness?” Ratio 14 (3), 234-251.

Hanel, P. H. P. and K. C. Vione. 2016. "Do student samples provide an accurate estimate of the general public?” PLoS One 11 (12): eo168354. doi:10.1371/journal.pone.o168354.

Innocenti, A. and M-G. Pazienza. 20o6. "Altruism and Gender in the Trust Game". Labsi Working Paper No. 5/2006. Available at ss RN: https://ssrn.com/abstract $=884378$ or http://dx.doi.org/10.2139/ssrn.884378.

Irwin, K., K. Edwards and J. A. Tamburello. 2015. "Gender, Trust and Cooperation in Environmental Social Dilemmas". Social Science Research 50, 328-342.

Jahan, S. (2016). Human Development Report 2016: Human Development for Everyone. The United Nations Development Programme (UNDP), New York, NY. 
Jeanquart-Barone, S. and U. Sekaran. 1994. "Effects of Supervisor's Gender on American Women's Trust." The Journal of Social Psychology 134 (2), 253-255.

Kollock, P. 1998. "Social Dilemmas: The Anatomy of Cooperation." Annual Review of Sociology 24 (1), 183-214.

Lengauer, G., F. Esser and R. Berganza. 2012. "Negativity in political news: A review of concepts, operationalizations and key findings." Journalism 13 (2), 179-202.

Lundmark, S., M. Gilljam and S. Dahlberg. 2016. "Measuring Generalized Trust: An Examination of Question Wording and the Number of Scale Points." Public opinion Quarterly 80 (1), 26-43.

Mayer, R. C., J. H. Davis and F. D. Schoorman. 1995. "An Integrative Model of Organizational Trust." Academy of Management Review 20 (3), 709-34.

Moffitt, T. E., A. Caspi, M. Rutter and P. A. Silva. 2001. Sex Differences in Antisocial Behavior: Conduct Disorder, Delinquency, and Violence in the Dunedin Longitudinal Study. Cambridge, UK: Cambridge University Press.

Nannestad, P. 20o8. "What Have We Learned About Generalized Trust, If Anything?" Annual Review of Political Science 11, 413-436.

Newton, K., D. Stolle and S. Zmerli. 2018. "Social and Political Trust”. In E. M. Uslaner (ed), The Oxford Handbook of Social and Political Trust. Oxford: Oxford University Press.

Roland B. and J. Tirole. 20o6. "Incentives and Prosocial Behavior." The American Economic Review 96 (5), 1652-1678.

Rosch, E. 1975. "Cognitive Representations of Semantic Categories." Journal of Experimental Psychology: General 104 (3), 192-233.

Rueckert, L. and N. Naybar. 2008. "Gender Differences in Empathy: The Role of the Right Hemisphere." Brain and Cognition 67 (2), 162-167.

Soroka, S. N. 2006. "Good News and Bad News: Asymmetric Responses to Economic Information." Journal of Politics 68 (2), 372-385.

Spence, J. T. and C. E. Buckner. (2000). "Instrumental and Expressive Traits, Trait Stereotypes, and Sexist Attitudes: What Do They Signify?" Psychology of Women Quarterly 24 (1), 44-62.

Swamy, A., S. Knack, Y. Lee and O. Azfar. 2001. "Gender and Corruption." Journal of Development Economics 64 (1), 25-55.

Wright, T. L. and E. G. Sharp. 1979. "Content and Grammatical Sex Bias on the Interpersonal Trust Scale and Differential Trust Toward Women and Men." Journal of Consulting and Clinical Psychology 47 (1), 72-85. 


\section{Appendix}

TABLE A1 Descriptive statistics socio-demographic variables

\begin{tabular}{|c|c|c|c|c|c|}
\hline & Obs. & Mean & Std.Dev. & Min & $\operatorname{Max}$ \\
\hline \multicolumn{6}{|l|}{ Germany } \\
\hline Age & 1,000 & 46.02 & 15.25 & 18 & 87 \\
\hline Gender $(\mathrm{m}=\mathrm{o}, \mathrm{f}=\mathbf{1})$ & 1,000 & $0.5^{\circ}$ & $0.5^{0}$ & o & 1 \\
\hline Left-Right dummy & $85^{8}$ & 0.46 & 0.50 & o & 1 \\
\hline Income dummy & 833 & $0.5^{2}$ & 0.50 & O & 1 \\
\hline Marital dummy & 967 & 0.60 & 0.49 & o & 1 \\
\hline \multicolumn{6}{|l|}{ Norway } \\
\hline Age & 1,000 & $49 \cdot 76$ & $17 \cdot 32$ & 18 & 87 \\
\hline $\operatorname{Gender}(\mathrm{m}=0, \mathrm{f}=1)$ & 1,000 & 0.51 & $0.5^{0}$ & o & 1 \\
\hline Left-Right dummy & 820 & 0.38 & 0.49 & o & 1 \\
\hline Income dummy & 1,000 & 0.46 & 0.50 & o & 1 \\
\hline Marital dummy & 939 & 0.70 & 0.46 & o & 1 \\
\hline \multicolumn{6}{|l|}{ U.S. } \\
\hline Age & 1,000 & 46.84 & 18.42 & 18 & 92 \\
\hline $\operatorname{Gender}(\mathrm{m}=\mathrm{o}, \mathrm{f}=\mathbf{1})$ & 1,000 & $0.5^{\circ}$ & $0.5^{\circ}$ & o & 1 \\
\hline Left-Right dummy & 809 & 0.49 & $0.5^{\circ}$ & o & 1 \\
\hline Income dummy & 911 & 0.43 & $0.5^{\circ}$ & o & 1 \\
\hline Marital dummy & 973 & 0.54 & $0.5^{\circ}$ & $\mathrm{O}$ & 1 \\
\hline \multicolumn{6}{|l|}{ Pooled } \\
\hline Age & 3,000 & $47 \cdot 54$ & 17.12 & 18 & 92 \\
\hline $\operatorname{Gender}(\mathrm{m}=0, \mathrm{f}=1)$ & 3,000 & $0.5^{\circ}$ & $0.5^{\circ}$ & o & 1 \\
\hline Left-Right dummy & 2,487 & 0.44 & $0.5^{\circ}$ & o & 1 \\
\hline Income dummy & 2,744 & 0.47 & $0.5^{\circ}$ & o & 1 \\
\hline Marital dummy & 2,879 & 0.61 & 0.49 & o & 1 \\
\hline
\end{tabular}


TABLE A2 Means test of the treatment effect

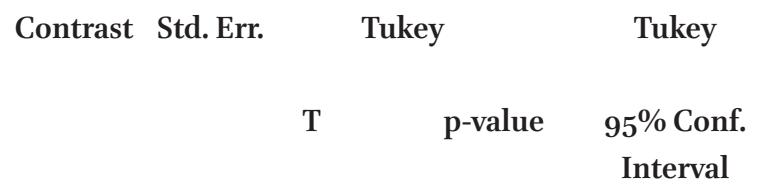

Norway 1

People vs. Men

0.26

0.18

1.43

$0.324-0.17$

0.69

0.456

Men vs. Women

0.59

0.18

3.23

0.004

$0.16 \quad 1.02$

0.004

People vs. Women

0.86

0.18

4.66

$<0.0005$

$0.42 \quad 1.29$

$<0.0005$

Norway 2

People vs. Men

0.77

0.16

4.92

$<0.0005 \quad 0.39$

$1.14<0.0005$

Men vs. Women

0.62

0.16

3.95

$<0.0005$

$0.24 \quad 0.99<0.0005$

People vs. Women

1.39

0.16

8.86

$<0.000$

1.01

$1.76<0.0005$

Germany

People vs. Men

$$
1.5^{2}
$$

0.17

8.72

$<0.0005$

1.11

$1.93<0.0005$

Men vs. Women

1.49

0.17

$8.5^{\circ}$

$<0.0005$

1.08

$1.90<0.0005$

People vs. Women

3.00

0.18

17.05

$<0.0005$

$2.59 \quad 3.42 \quad<0.0005$

\section{United States}

\begin{tabular}{lccccccc} 
People vs. Men & 0.54 & 0.18 & 3.04 & 0.007 & 0.12 & 0.95 & 0.007 \\
Men vs. Women & 2.20 & 0.18 & 12.34 & $<0.0005$ & 1.78 & 2.61 & $<0.0005$ \\
People vs. Women & 2.73 & 0.17 & 15.73 & $<0.0005$ & 2.32 & 3.14 & $<0.0005$ \\
\hline
\end{tabular}

Note: Sample size for "People", "Men", "Women": Norwayı (N=333/335/333), Norway2 (N=333/ $334 / 333)$, Germany (N=331/342/327), U.S. (N=350/317/333). 
TABLE A3 Multivariate analysis of trust, selfishness and covariates (OLS)

\section{Trust in Women}

DE US NO Pooled
(1)
(2)
(3)
(4)

\begin{tabular}{llccc}
\hline Women are more selfish & -.467 & $-2.038^{* * *}$ & $-1.914^{* * *}$ & $-1.256^{* * *}$ \\
& $(.469)$ & $(.497)$ & $(.501)$ & $(.278)$
\end{tabular}

Men are more selfish

$\begin{array}{lcccc}\text { Age } & .013 & .013 & .002 & .010^{*} \\ \text { Gender }(\mathrm{m}=\mathrm{O}, \mathrm{f}=1) & (.012) & (.008) & (.008) & (.005) \\ & .424 & .517 & -.147 & .247 \\ \text { Left-Right } & (.345) & (.28) & (.248) & (.165) \\ \text { Income dummy } & -.050 & -.102 & -.304 & -.160 \\ & (.332) & (.284) & (.263) & (.167) \\ \text { Partner (n=0, y=1) } & .367 & .747^{*} & -.069 & .476^{*} \\ \text { Education dummy } & (.382) & (.308) & (.26) & (.18) \\ & .245 & .078 & .684^{*} & .295 \\ \text { Norway country dummy } & (.382) & (.307) & (.283) & (.182) \\ & .840^{*} & .386 & .385 & .546^{* *} \\ \text { U.S. country dummy } & (.365) & (.289) & (.264) & (.173) \\ & & & & .720^{* * *} \\ \text { Observations } & & & & (.211) \\ \text { Adjusted R-squared } & & & .620^{* *} \\ \end{array}$

Note: Trust-Women-Q (o/1) indicating treatment, Selfishness (o/1), 1 for anyone saying men are more selfish, o if the respondent answered women are more selfish or equal for both genders. Gender (o=men, $1=$ women). Left-Right uses party choice, 1 in Norway for Høyre and Fremskrittspartiet, 1 in Germany for CDU/CSU and AfD, 1 in the US for Republicans. High income is 1 for anyone with a household income above the median in the country sample. Partner (o/1) denotes anyone reporting they are married, cohabiting or non-single. Age is a continuous variable. Germany is a country dummy. ${ }^{*} \mathrm{p}<.05,{ }^{* *} \mathrm{p}<.01,{ }^{* * *} \mathrm{p}<.001$. 


\section{Trust in Men}

\section{Trust in People}

$\begin{array}{llllllll}\text { DE } & \text { US } & \text { NO } & \text { Pooled } & \text { DE } & \text { US } & \text { NO } & \text { Pooled } \\ (5) & (6) & (7) & (8) & (9) & (10) & (11) & (12)\end{array}$

\begin{tabular}{|c|c|c|c|c|c|c|c|}
\hline $\begin{array}{l}-.911^{* *} \\
(.301)\end{array}$ & $\begin{array}{c}-1.595^{* * *} \\
(.319)\end{array}$ & $\begin{array}{l}-.671^{*} \\
(.260)\end{array}$ & $\begin{array}{c}-1.074^{* * *} \\
(.169)\end{array}$ & $\begin{array}{l}-.246 \\
(.320)\end{array}$ & $\begin{array}{l}-.261 \\
(.292)\end{array}$ & $\begin{array}{c}.044 \\
(.258)\end{array}$ & $\begin{array}{l}-.141 \\
(.166)\end{array}$ \\
\hline $\begin{array}{l}-.004 \\
(.01)\end{array}$ & $\begin{array}{l}.01 \\
(.008)\end{array}$ & $\begin{array}{c}.009 \\
(.007)\end{array}$ & $\begin{array}{c}.006 \\
(.005)\end{array}$ & $\begin{array}{l}.022^{*} \\
(.01)\end{array}$ & $\begin{array}{c}.008 \\
(.007)\end{array}$ & $\begin{array}{l}.042^{* * *} \\
(.007)\end{array}$ & $\begin{array}{l}.025^{* * *} \\
(.004)\end{array}$ \\
\hline $\begin{array}{l}-.396 \\
(.291)\end{array}$ & $\begin{array}{l}-.098 \\
(.297)\end{array}$ & $\begin{array}{c}.247 \\
(.245)\end{array}$ & $\begin{array}{l}-.116 \\
(.16)\end{array}$ & $\begin{array}{l}.876^{* *} \\
(.290)\end{array}$ & $\begin{array}{l}-.44 \\
(.26)\end{array}$ & $\begin{array}{c}.046 \\
(.239)\end{array}$ & $\begin{array}{c}.113 \\
\left(.15^{1}\right)\end{array}$ \\
\hline $\begin{array}{c}.327 \\
(.289)\end{array}$ & $\begin{array}{c}.392 \\
(.307)\end{array}$ & $\begin{array}{l}-.121 \\
(.258)\end{array}$ & $\begin{array}{c}.202 \\
(.163)\end{array}$ & $\begin{array}{l}-.295 \\
(.276)\end{array}$ & $\begin{array}{c}.07 \\
(.27)\end{array}$ & $\begin{array}{l}-.326 \\
(.246)\end{array}$ & $\begin{array}{l}-.131 \\
(.153)\end{array}$ \\
\hline $\begin{array}{c}.097 \\
(.297)\end{array}$ & $\begin{array}{l}.485 \\
(.338)\end{array}$ & $\begin{array}{l}-.625^{*} \\
(.261)\end{array}$ & $\begin{array}{l}-.049 \\
(.171)\end{array}$ & $\begin{array}{c}.554 \\
(.296)\end{array}$ & $\begin{array}{c}.293 \\
(.288)\end{array}$ & $\begin{array}{c}.266 \\
(.255)\end{array}$ & $\begin{array}{l}.310 \\
(.161)\end{array}$ \\
\hline $\begin{array}{c}.453 \\
(.322)\end{array}$ & $\begin{array}{c}.215 \\
(.325)\end{array}$ & $\begin{array}{l}1.017^{* * *} \\
(.275)\end{array}$ & $\begin{array}{l}.590^{* * *} \\
(.175)\end{array}$ & $\begin{array}{l}-.171 \\
(.308)\end{array}$ & $\begin{array}{c}.204 \\
(.289)\end{array}$ & $\begin{array}{l}-.25^{2} \\
(.273)\end{array}$ & $\begin{array}{l}-.053 \\
(.168)\end{array}$ \\
\hline \multirow[t]{2}{*}{$\begin{array}{c}.477 \\
(.298)\end{array}$} & $\begin{array}{l}.818^{* *} \\
(.31)\end{array}$ & $\begin{array}{l}.075 \\
(.260)\end{array}$ & $\begin{array}{l}.501^{* *} \\
(.166)\end{array}$ & $\begin{array}{l}.819^{* *} \\
(.298)\end{array}$ & $\begin{array}{l}-.155 \\
(.265)\end{array}$ & $\begin{array}{l}.317 \\
(.246)\end{array}$ & $\begin{array}{l}.35^{2} \\
(.154)\end{array}$ \\
\hline & & & $\begin{array}{l}1.684^{* * *} \\
(.195) \\
-.263 \\
(.198)\end{array}$ & & & & $\begin{array}{l}2.409^{* * *} \\
(.191) \\
1.004^{* * *} \\
(.189)\end{array}$ \\
\hline 245 & 224 & $25^{1}$ & 720 & 220 & 264 & 263 & 747 \\
\hline .052 & .159 & .084 & .223 & .077 & .013 & .118 & .235 \\
\hline
\end{tabular}


TABLE A4 Multivariate analysis with alternative coding for selfishness (OLS)

\section{Trust in Women}

$\begin{array}{llll}\text { DE } & \text { US } & \text { NO } & \begin{array}{l}\text { Pooled } \\ (1)\end{array} \\ (2) & (3) & (4) \\ -0.406 & -2.199^{* * *} & -2.274^{* * *} & -1.308^{* * *} \\ (0.508) & (0.588) & (0.570) & (0.322)\end{array}$

Men are more selfish

\begin{tabular}{|c|c|c|c|c|}
\hline Age & $\begin{array}{c}0.007 \\
(0.016)\end{array}$ & $\begin{array}{c}0.018 \\
(0.014)\end{array}$ & $\begin{array}{l}-0.013 \\
(0.013)\end{array}$ & $\begin{array}{c}0.003 \\
(0.008)\end{array}$ \\
\hline Gender $(\mathrm{m}=0, \mathrm{f}=\mathbf{1})$ & $\begin{array}{c}0.315 \\
(0.496)\end{array}$ & $\begin{array}{c}1.031^{*} \\
(0.515)\end{array}$ & $\begin{array}{l}-0.721 \\
(0.448)\end{array}$ & $\begin{array}{c}0.133 \\
(0.279)\end{array}$ \\
\hline Left-Right & $\begin{array}{l}-0.009 \\
(0.456)\end{array}$ & $\begin{array}{c}0.366 \\
(0.520)\end{array}$ & $\begin{array}{l}-0.627 \\
(0.425)\end{array}$ & $\begin{array}{l}-0.15^{2} \\
(0.274)\end{array}$ \\
\hline Income dummy & $\begin{array}{c}0.326 \\
(0.522)\end{array}$ & $\begin{array}{c}0.440 \\
(0.567)\end{array}$ & $\begin{array}{l}-0.178 \\
(0.437)\end{array}$ & $\begin{array}{c}0.347 \\
(0.293)\end{array}$ \\
\hline Partner $(n=0, y=1)$ & $\begin{array}{c}0.209 \\
(0.523)\end{array}$ & $\begin{array}{l}-0.511 \\
(0.546)\end{array}$ & $\begin{array}{c}0.742 \\
(0.508)\end{array}$ & $\begin{array}{c}0.068 \\
(0.304)\end{array}$ \\
\hline Education dummy & $\begin{array}{c}0.874 \\
\left(0.5^{11}\right)\end{array}$ & $\begin{array}{c}0.476 \\
\left(0.5^{28}\right)\end{array}$ & $\begin{array}{l}-0.539 \\
(0.429)\end{array}$ & $\begin{array}{c}0.323 \\
(0.280)\end{array}$ \\
\hline Norway country dummy & & & & $\begin{array}{c}0.580 \\
(0.331)\end{array}$ \\
\hline U.S. country dummy & & & & $\begin{array}{c}0.577 \\
(0.323)\end{array}$ \\
\hline Observations & 113 & 82 & 82 & 277 \\
\hline Adjusted R-squared & -0.014 & 0.184 & 0.159 & 0.078 \\
\hline
\end{tabular}

Note: Trust-Women-Q (o/1) indicating treatment, Selfishness (o/1), 1 for anyone saying men are more selfish, o if the respondent answered women are more selfish. Gender (o=men, $1=$ women). Left-Right uses party choice, 1 in Norway for Høyre and Fremskrittspartiet, 1 in Germany for CDU/CSU and AfD, 1 in the US for Republicans. High income is 1 for anyone with a household income above the median in the country sample. Partner (o/1) denotes anyone reporting they are married, cohabiting or non-single. Age is a continuous variable. Germany is a country dummy. ${ }^{*} \mathrm{p}<.05,{ }^{* *} \mathrm{p}<.01,{ }^{* * *} \mathrm{p}<.001$. 


\section{Trust in Men}

DE

(5)

(6)

US

NO

Pooled

DE

US

NO

Pooled

(7)

(8)

(9)

(10)

(11)

(12)

\begin{tabular}{|c|c|c|c|c|c|c|c|}
\hline $\begin{array}{l}-1.367^{* *} \\
(0.478)\end{array}$ & $\begin{array}{l}-1.249^{*} \\
(0.584)\end{array}$ & $\begin{array}{l}-0.648 \\
(0.466)\end{array}$ & $\begin{array}{l}-1.05^{* * *} \\
(0.286)\end{array}$ & $\begin{array}{c}0.596 \\
(0.542)\end{array}$ & $\begin{array}{c}0.097 \\
(0.512)\end{array}$ & $\begin{array}{c}0.325 \\
(0.485)\end{array}$ & $\begin{array}{c}0.417 \\
(0.285)\end{array}$ \\
\hline $\begin{array}{l}-0.019 \\
(0.014)\end{array}$ & $\begin{array}{c}0.008 \\
(0.014)\end{array}$ & $\begin{array}{c}0.017 \\
(0.013)\end{array}$ & $\begin{array}{c}0.002 \\
(0.008)\end{array}$ & $\begin{array}{l}0.046 * * \\
(0.016)\end{array}$ & $\begin{array}{l}-0.002 \\
(0.012)\end{array}$ & $\begin{array}{l}0.039^{* *} \\
(0.012)\end{array}$ & $\begin{array}{l}0.025^{* * *} \\
(0.007)\end{array}$ \\
\hline $\begin{array}{l}-0.571 \\
(0.442)\end{array}$ & $\begin{array}{l}-0.154 \\
(0.508)\end{array}$ & $\begin{array}{l}-0.471 \\
(0.418)\end{array}$ & $\begin{array}{l}-0.488 \\
(0.256)\end{array}$ & $\begin{array}{c}0.859 \\
(0.501)\end{array}$ & $\begin{array}{l}-1.043^{*} \\
(0.435)\end{array}$ & $\begin{array}{c}0.347 \\
(0.403)\end{array}$ & $\begin{array}{c}0.071 \\
(0.253)\end{array}$ \\
\hline $\begin{array}{c}0.721 \\
(0.434)\end{array}$ & $\begin{array}{c}0.677 \\
(0.551)\end{array}$ & $\begin{array}{l}-0.684 \\
(0.428)\end{array}$ & $\begin{array}{c}0.180 \\
(0.264)\end{array}$ & $\begin{array}{l}-0.162 \\
(0.460)\end{array}$ & $\begin{array}{l}-0.301 \\
(0.478)\end{array}$ & $\begin{array}{c}0.413 \\
(0.416)\end{array}$ & $\begin{array}{c}0.15^{8} \\
(0.253)\end{array}$ \\
\hline $\begin{array}{l}-0.401 \\
(0.456)\end{array}$ & $\begin{array}{l}-0.087 \\
(0.604)\end{array}$ & $\begin{array}{l}-0.463 \\
(0.435)\end{array}$ & $\begin{array}{l}-0.427 \\
(0.275)\end{array}$ & $\begin{array}{l}1.413^{* *} \\
(0.508)\end{array}$ & $\begin{array}{c}0.865 \\
(0.465)\end{array}$ & $\begin{array}{c}0.592 \\
(0.414)\end{array}$ & $\begin{array}{l}0.766^{* *} \\
(0.262)\end{array}$ \\
\hline $\begin{array}{c}1.045^{*} \\
(0.480)\end{array}$ & $\begin{array}{c}0.541 \\
(0.615)\end{array}$ & $\begin{array}{l}1.686 * * * \\
(0.443)\end{array}$ & $\begin{array}{l}1.238^{* * *} \\
(0.284)\end{array}$ & $\begin{array}{l}-1.129^{*} \\
(0.517)\end{array}$ & $\begin{array}{c}0.033 \\
(0.485)\end{array}$ & $\begin{array}{l}-0.596 \\
(0.442)\end{array}$ & $\begin{array}{l}-0.463 \\
(0.269)\end{array}$ \\
\hline \multirow[t]{3}{*}{$\begin{array}{c}0.207 \\
(0.444)\end{array}$} & $\begin{array}{c}1.156^{*} \\
(0.523)\end{array}$ & $\begin{array}{c}0.044 \\
(0.435)\end{array}$ & $\begin{array}{c}0.425 \\
(0.264)\end{array}$ & $\begin{array}{c}0.834 \\
(0.497)\end{array}$ & $\begin{array}{l}-0.191 \\
(0.459)\end{array}$ & $\begin{array}{c}0.391 \\
(0.402)\end{array}$ & $\begin{array}{c}0.420 \\
(0.255)\end{array}$ \\
\hline & & & $\begin{array}{l}1.622^{* * *} \\
(0.305)\end{array}$ & & & & $\begin{array}{l}2.622^{* * *} \\
(0.308)\end{array}$ \\
\hline & & & $\begin{array}{l}-0.689 * \\
(0.314)\end{array}$ & & & & $\begin{array}{l}0.892^{* *} \\
(0.318)\end{array}$ \\
\hline 118 & 93 & 110 & 321 & 89 & 95 & 109 & 293 \\
\hline 0.112 & 0.099 & $0.15^{2}$ & 0.254 & 0.136 & 0.037 & 0.087 & $0.25^{8}$ \\
\hline
\end{tabular}




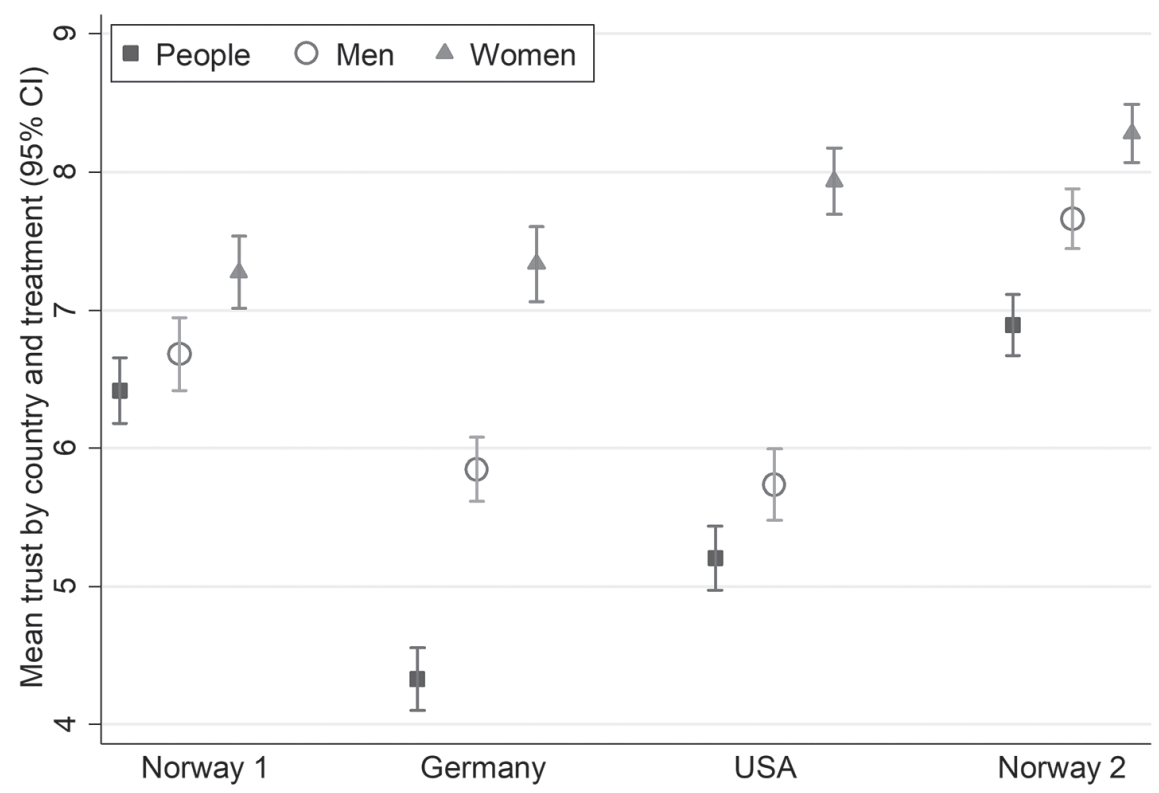

FIGURE A1 Treatment effect with Pilot study (Norway 1) 